\title{
FOOD PREFERENCE AND THE EFFECT OF PREDATOR CUES ON THE FORAGING BEHAVIOUR OF HOUSE RAT (Rattus tanezumi)
}

\author{
WONG LOK JINN ${ }^{1}$ and ANDREW ALEK TUEN ${ }^{2 *}$ \\ ${ }^{1}$ Faculty of Resource Science and Technology, \\ Universiti Malaysia Sarawak, Malaysia \\ ${ }^{2}$ Institute of Biodiversity and Environmental Conservation, \\ Universiti Malaysia Sarawak, Malaysia \\ *E-mail: aatuen@unimas.my
}

Accepted 26 July 2020, Published online 31 December 2020

\begin{abstract}
The House Rat (Rattus tanezumi) is a major pest in the agriculture and food industry, a carrier of zoonotic diseases, and a source of nuisance to society. Poisoning is not an ecologically desirable method to control the rat population due to its effect on non-target animals. This article reported on the use of predator cues to control the rat's foraging behavior. Food preference for sugarcane, corn, oil palm fruit, and young coconut flesh was determined first using a modified "cafeteria method" with a central cage connected to four feeding stations by PVC tubes. Then the effect of predator cues (3-D model and call of an owl, a combination of model and call and no predator cue as control) on foraging behavior was tested by manipulating these cues near the feeding station. Giving up density (GUD), which is the amount of food remaining at the feeding stations, was measured in both experimental phases. Treatment means were analyzed using ANOVA and compared using the Tukey test. The finding showed that House Rats preferred young coconut flesh over other test foods. All predator cues increased GUD significantly $(p<0.01)$ but the 3 -D model was the most effective. This study suggests a potential use of predator cues to control rat pest.
\end{abstract}

Key words: House rat (Rattus tanezumi), visual cue, auditory cue, giving-up density (GUD), foraging behavior

\section{INTRODUCTION}

Rodent, with 2,552 species worldwide (Burgin et al., 2018), is the most diverse and successful mammalian group in the world. They play various ecological roles such as seed dispersal, assisting in nutrient cycling through faecal deposition (Pimsai et al., 2014) as well as being an important prey base for many predator species (Witmer, 2004). Rats are also a major pest of crops by competing for food with humans and livestock leading to significant economic loss (Singleton, 2003; Stenseth et al., 2003; Rehman et al., 2019). A study in Indonesia estimated that every $1 \%$ increase in tiller damage by rats translates to $58 \mathrm{~kg} / \mathrm{ha}$ loss in rice yield (Singleton et al., 2005). Rattus tiomanicus attacked oil palm at all stages of growth, causing $5-30 \%$ damage to fruits and $7-10 \%$ of the palms (Wood \& Chung, 2003). Wood and Chung, (2003)

\footnotetext{
* To whom correspondence should be addressed.
}

estimated damage due to rats ranged from USD48-288/ha, depending on the price of palm oil. Meanwhile, the close association of some murids with a human has brought health concern of zoonotic diseases (Himsworth et al., 2013; Kosoy et al., 2015; Strand \& Lundkvist, 2019; Modlinska \& Pisula, 2020).

Methods of managing the rat population have included trapping, poisoning, and biological control. Poisons such as anticoagulant rodenticides have been used successfully to control the rat population in agricultural areas (Wood \& Chung, 2003; Atta et al., 2018) but there is evidence that rats are developing some resistance to them (Lam, 1982; Quy et al., 1995; Andru et al., 2013; Strand \& Lundkvist, 2019). The use of poison is ecologically inappropriate and undesirable due to its secondary effect on non-target animals (Howald et al., 1999; Serieys et al., 2019). The barn owl has been used to control the rat population in rice fields and oil palm plantations in Malaysia (Hafidzi \& 
Naim, 2003; Wood \& Chung, 2003; Puan et al., 2011) either on its own or together with rodenticide. The combination of the barn owl and rodenticide has proven to be more effective than either method alone, but the poison has lethal as well as a nonlethal but negative effect on the owl (Salim et al., 2014; Omar et al., 2016). The presence of owl has also reduced the cost of rodenticide application by $53-60 \%$ (Kross \& Baldwin, 2016) while Duckett, (1991) estimated the cost of using barn owl is only $20 \%$ the cost of baiting.

The idea of using owl in rice fields and oil palm plantations is to kill the rat thereby reducing its population through the natural biological cycle. However, the reduction in crop damage due to the presence of the owl is more than what is estimated from the number of rats killed, based on remains under the nesting boxes (Smal, 1990). Studies by Puan et al. (2011) and Naim et al. (2014) established a relationship through which the damage to oil palm fruits can be estimated from the number of rat present. This suggests that fear of predator (nonlethal effect) may indeed be a bigger contributor to the owl effect. According to Wang et al. (2016), direct killing by predators alters the behavior and physiology of the prey to such an extent that they are more fearful of perceived predation than direct predation. Studies with predator cues showed that prey responded to predator cues (urine, playback recorded calls, scent and fecal odor of a predator), by reducing their foraging activity in exposed areas that they perceived as risky (Hendrie et al., 1998; Orrock et al., 2004; Sivy et al., 2011; SanchezGonzalez et al., 2018). This suggests the potential of using predator cues instead of real predators to control rodent pests. Predator cues have the advantage over real predators as they can be used in all scenarios and may still elicit a behavioral response from prey.

We used a "modified cafeteria test" method to determine which locally available food types are preferred by House Rats and then test the effect of predator cues (3-D owl model, owl calls, a combination of owl calls and 3-D model and without predator cue) on the rat's foraging behavior towards its preferred food. Also, Scops owl was chosen as the origin of predator cues because it is common in Borneo (Puan et al., 2015) and its call can be heard clearly in oil palm plantation (Mohd Azlan et al., 2019), suburban areas (Puan, 2013) and forest at night.

Optimal foraging theory defines how an organism makes the best foraging decision to maximize energy intake, minimize handling time, and based on not only the quantity but the nutritional content of the food (Pyke, 1984). A higher $\mathrm{GuD}$ indicates a higher perceived risk of predation (Brown, 1999), higher environmental or psychological stress, or less valuable food (Tuen \& Brown, 1996). A subset of the optimal foraging theory is the optimal diet theory, which states that animals should prefer foods that yield more energy per unit handling time (Pulliam, 1974; Sih \& Christensen, 2001). The optimal diet of an animal also can be affected by predators, real or perceived. The predator effect increased the cost of foraging of an animal through increased vigilance, decreased the animal's energy intake, and left higher GuDs of food behind. Based on previous research studies, it is hypothesized that (i) rodents will show a food preference by having a lower GuDs on preferred food (Bernard, 2003; Sivy et al., 2011), (ii) predator cue will affect the foraging behavior of rodent by having a higher GuDs on preferred food (Abramsky et al., 1996; Hendrie et al., 1998; Sivy et al., 2011; Mahlaba et al., 2017).

\section{MATERIALS AND METHODS}

Four House Rats (R. tanezumi), consisting of three males and one female (non-pregnant and nonlactating) captured in Universiti Malaysia Sarawak (UNIMAS) campus and nearby residential area using live cage traps (Aplin et al., 2003) were used for this study. Each rat was placed individually in a wire cage $(50 \mathrm{~cm} \times 50 \mathrm{~cm} 30 \mathrm{~cm})$, which was connected to four feeding stations by four $50 \mathrm{~cm}$ long PVC tubes, with a diameter of $10 \mathrm{~cm}$ each (Figure 1). The rats were acclimatized to their cages for three days before the experimental trials, fed on pellets and water before the treatment phase was applied (Eilam et al., 1999; Morris \& Davidson, 2000). The treatment phase was the food preference experiment and predator cue experiment. All tests were done simultaneously on all four rats.

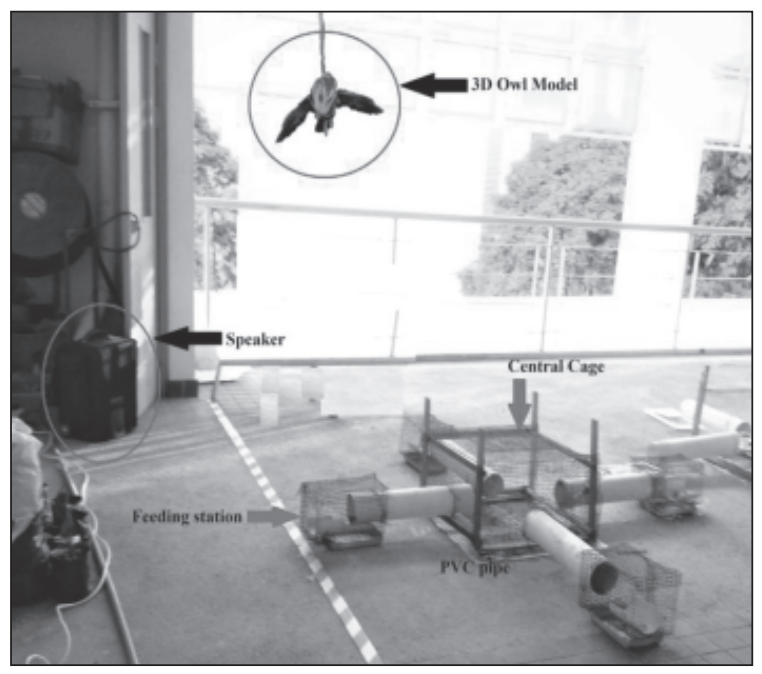

Fig. 1. "Modified" cafeteria test which has a square central cage with four feeding stations (adapted from Murua et al., 1980) that are connected to the central cage via a PVC tube. 
The food preference experiment followed the "modified cafeteria test" method of Murua et al., (1980) by placing a rat in a central rectangular cage surrounded by four tubes instead of a central octagonal cage surrounded by eight tubes. In each feeding station, $20 \mathrm{~g}$ of raw food material (sugarcane without the outer layer, corn kernel, oil palm fruit, and young coconut flesh which is removed from the nut) were placed separately. House Rats are known to cause damage to crops like maize, sugarcane, oil palm (Rehman et al., 2019), and coconut (Hegade et al., 2017). The foods were rotated to avoid bias due to the location of the feeding station. The foods were offered in the evening (5:00 p.m.) and left for $24 \mathrm{hr}$. The leftover was collected in the following evening (5:00 p.m.) and weighed. This multi-choicefeeding test was carried out for four days for each individual rat and was replicated with four different rats ( $n=16$ for each bait, $4 \times 4$ latin square design).

For the predator cue experiment, we tested (i) auditory cue, in which the calls of a Scops owl (obtained from xeno-canto) were played back once every 15 min interval using a speaker, which was $1.5 \mathrm{~m}$ away from the nearest feeding station; (ii) visual cue, which is a $3-\mathrm{D}$ model of the owl, $1.5 \mathrm{~m}$ diagonally above floor level from the nearest feeding station (Figure 2); (iii) combination of the auditory and visual cue; and (iv) no predator cue, as control. These treatments were conducted using the rat's most preferred food (young coconut flesh) identified from the previous experiment. Exposure to treatment was carried out simultaneously on four rats over four consecutive days. The calls were played intermittently within $12 \mathrm{hr}$ and the 3-D model of the owl was hanged for $12 \mathrm{hr}$.

Data collected was in the form of giving up density (GUD) which is expressed as the amount of food left behind by the rat after each night of foraging (Brown, 1988). The experimental design was a 44 Latin square for the food preference experiment. The data was analyzed using One-way ANOVA for both experiments, and the GuD means were compared using the Tukey test at $p=0.05$.

\section{RESULTS}

\section{Food preference}

All rats showed exploratory behavior by visiting the four food types as soon as it had presented them. The rats also exhibited hoarding behavior as shown by the presence of food inside the pipe connecting the feeding stations and the central arena of the cage.

Figure 3 presents the bar graph with mean values $(+$ S.E.) of the GUDs for the four different test foods. From the graph, young coconut flesh was preferred by the rats as it showed the lowest value

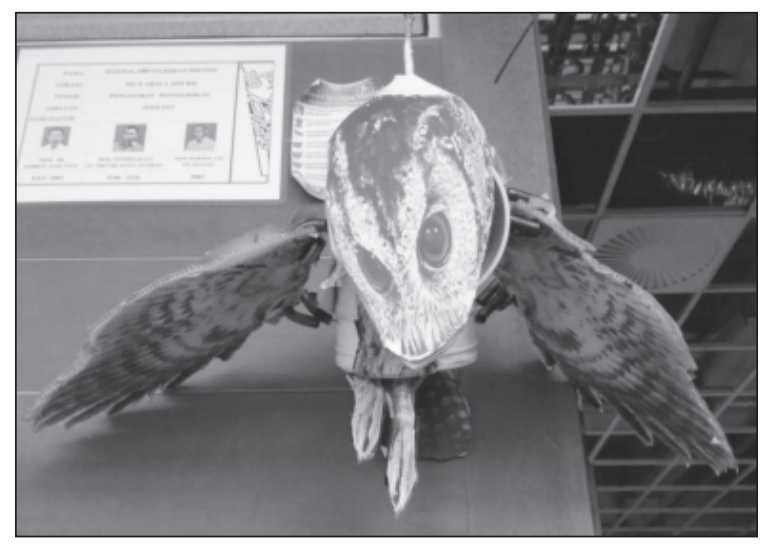

Fig. 2. A 3-D owl model is used as a predator cue.

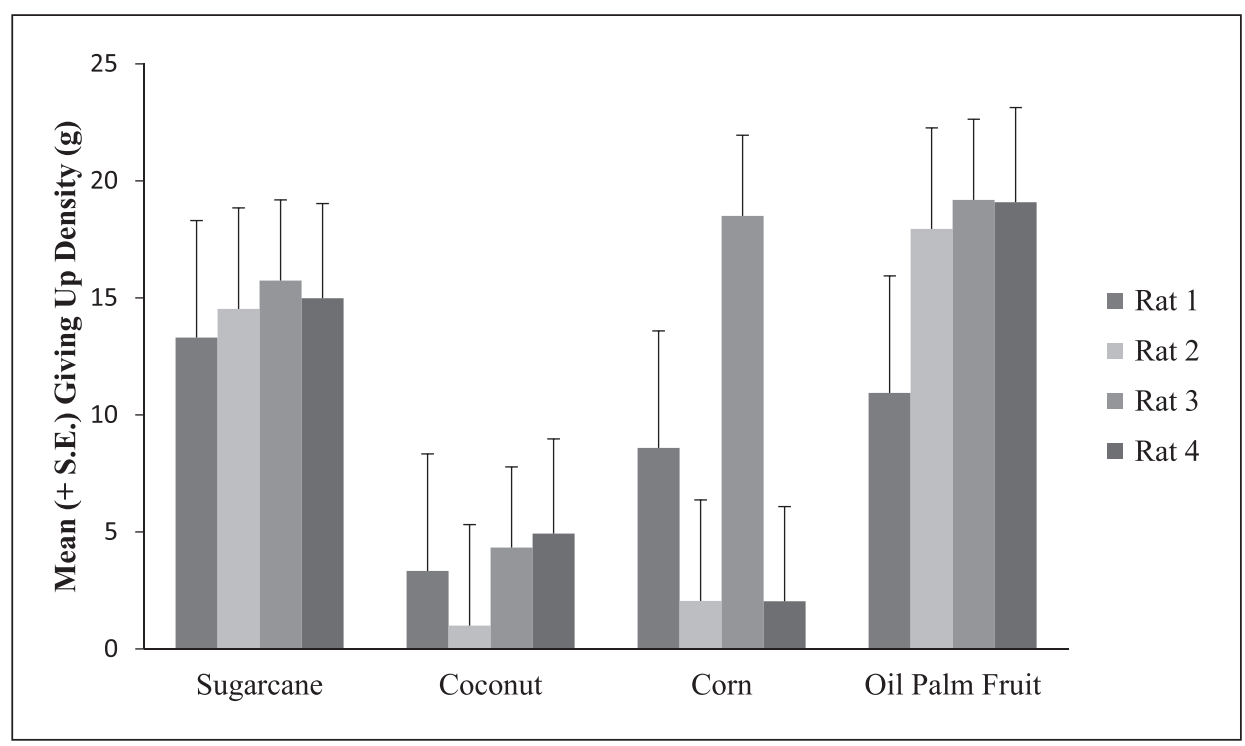

Fig. 3. Effects of food types on giving-up densities in food trays by the rats. Lower values represent a stronger preference for food. 
of GUDs while oil palm fruit is the least favored, with the highest value of GUDs.

ANOVA on GUD showed statistically significant differences between means $(p<0.01)$. Tukey test indicated that the mean of GUD of coconut $(3.4 \mathrm{~g})$ was significantly different $(p<0.05)$ from that of oil palm (16.79 g) and sugarcane $(14.64 \mathrm{~g})$ but not from corn $(7.79 \mathrm{~g})$ (Table 1).

\section{Effect of predator cues}

Figure 4 shows the bar graph with mean values (+ S.E.) of the GUDs under the influence of predator cues versus no predator cue. All rats responded to the predator cues by having a much higher GUD for their preferred food, which is the flesh of the young coconut, compared to when the predator cue was absent. Interestingly among the predator cues tested in this study, a visual cue (3-D owl model) has the greatest effect while an auditory cue (owl call) has the least effect.

ANOVA showed highly significant effects of treatments, with $p=0.00000001$, indicating that all predator cues strongly influenced the foraging behavior of rodents. The Tukey test at $p=0.05$ showed that the GUD of rats frightened with the 3-D owl model (15.52 g) is significantly different from owl call $(12.31 \mathrm{~g})$ and the effect of all the predator cues are significantly different compared to the control (Table 2).

\section{DISCUSSION}

\section{Food preference}

The result demonstrated that House Rats showed lower GUDs on their preferred food which is the young coconut flesh. The animal's food preference is influenced by the physical and chemical characteristics of food, especially characteristics that influence palatability. The choice of the rat is influenced by the palatability of food which varies in texture, color, hardness, and taste. The food also varies in terms of fiber contents, the gross energy values, and the source of energy. Sugarcane has the highest crude fiber content (23.5\% of DM, Mui et al., 2000) while young coconut has the least $(0.61 \%$, Wynn, 2017). Rats, being monogastric animals, cannot digest fiber, and the fiber content of more than $5 \%$ is detrimental to its digestion and often avoided (Caroline et al., 2003). Adam et al. (2014) detected increased circulation of satiety hormone in the blood of rats fed diets containing fermentable dietary fiber leading to reduced food intake. Young coconut also has the highest gross energy value $(32.1 \mathrm{MJ} / \mathrm{kg} \mathrm{DM}$ gross energy, Hauze et al., 2015) compared to

Table 1. Result of Tukey test on mean GUDs (g) for food preference experiment. Values showing different superscript letters are significantly different at $p=0.05$

\begin{tabular}{lccc}
\hline Coconut & Corn & Sugarcane & Oil Palm Fruit \\
\hline $3.40 .86^{\mathrm{a}}$ & $7.79^{\mathrm{ac}}$ & $14.64^{\mathrm{bc}}$ & $16.79^{\mathrm{bc}}$ \\
\hline
\end{tabular}

Table 2. Result of Tukey test on the mean GUD (g) of predator cue and control (no predator cue). Values with different superscript letters are significantly different at $p=0.05$

\begin{tabular}{cccc}
\hline Control & Owl Call & Combination & 3-D Owl Model \\
\hline $3.40^{\mathrm{a}}$ & $12.31^{\mathrm{bc}}$ & $14.20^{\mathrm{cd}}$ & $15.52^{\mathrm{d}}$ \\
\hline
\end{tabular}

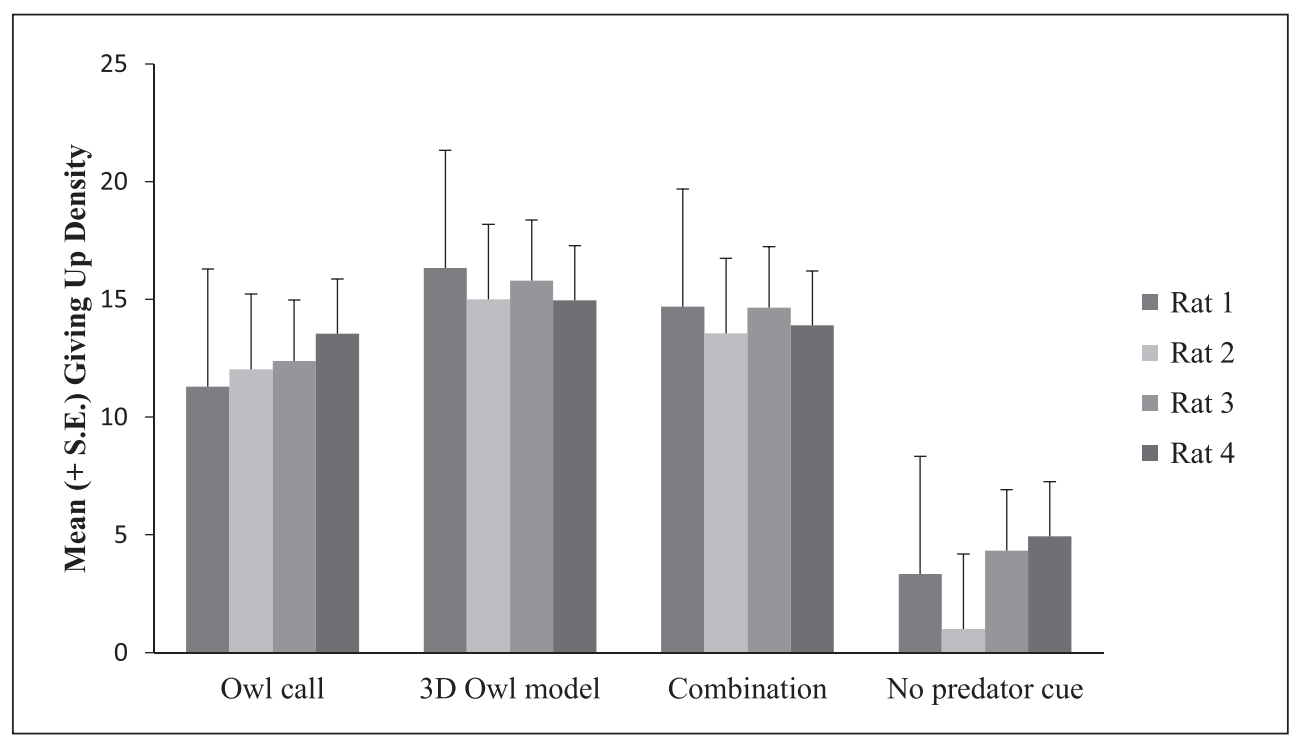

Fig. 4. Effects of predator cues on giving up densities of rats for preferred food. 
sugarcane $(18 \mathrm{MJ} / \mathrm{kg} \mathrm{DM}$ gross energy, Hauze et al., 2018a), corn (16.6 MJ/kg DM gross energy, Kwon \& Kim, 2015), and oil palm fruit (16.7 MJ/kg DM, Hauze et al., 2018b). Coconut, corn, and sugarcane have carbohydrates as the main source of energy while oil palm fruit has fat as the main source of energy. Hegab et al. (2014) found that Norway Rats preferred corn over other novel food types, showing a significant positive correlation with carbohydrates, suggesting this rat choose food with high energy content. The total intake of energy will determine the growth of the animal. In this study, all House Rats gained $10 \mathrm{~g}$ on average due to high energy consumption than energy expenditure, notably due to the restricted space in the arena (ChalvonDemersay et al., 2017).

Whether the House Rat select food based on its chemical composition or physical characteristics cannot be ascertained in this study. It is more logical to assume that the rats having tried each of the food on offer then decided as to which one they prefer. Despite having a reputation of being neophobic (fear of new things) rats are always curious, and they tried to sample and approach a new food cautiously (Whishaw \& Whishaw, 1996; Hegab et al., 2014). Rats have a remarkably strong and welldeveloped sense of smell, which it uses more than their other senses, to locate and discover potential food sources (Bessieres et al., 2017; Carlson et al., 2018). In the food preference test, the House Rats revealed their curiosity by trying every food which was provided in each station.

\section{Effect of predator cues on foraging behavior}

All rats responded to the predator cues by having a much higher GUD for their preferred food, which is the flesh of the young coconut, compared to when the predator cue was absent. The increased in GUDs for young coconut flesh in the presence of predator ranged from $8 \mathrm{~g}$ for owl call to $12 \mathrm{~g}$ for 3-D model, respectively. At the gross energy content of $32.1 \mathrm{~kJ} / \mathrm{g}$, this represents an energy cost amounting to 257 to $385 \mathrm{~kJ}$, which is huge compared to the energy required for growth of $213 \mathrm{~kJ} /$ day for a $100 \mathrm{~g}$ rat $(\mathrm{NRC}, 1995)$.

The increase in GUD was the result of reduced foraging activity as reported by Brown et al. (1988), Abramsky et al. (1996), Sivy et al. (2011), and Mahlaba et al. (2017). Abramsky et al. (1996) reported that gerbils responded to predation risk from barn owl by avoiding risky open areas and limiting their activity to bush habitat. The flight of barn owl elicited the strongest response and its hunger call the least (Abramsky et al., 1996). Similarly, a visual cue (3-D image of owl) has a significantly greater effect on GUD compared to an auditory cue (owl call) in the current study.
According to Bovet and Vauclair, (2000), many animals responded to pictures of their predator and behaved in similar ways to real-life objects. A study by Pongracz and Altbacker, (2000) also showed that a stuffed predator increased the defensive response of the rabbit, although it had no previous experience with predators. The findings suggested that prey might possess an inherited "picture" of a predator.

The GUDs of owl call is the lowest among the predator cues used in this experiment, meaning it was the least scary of the predator cues. Studies by Hendrie et al. (1998) suggest that species of wild rodents exhibited a different behavioral response to owl calls, ranging from no response to spending more time in their burrows. Eilam et al. (1999) showed that the behavior of spiny mice did not change when exposed to owl call although elevated cortisol levels indicated the rats were stressed by it. Another potential explanation is that the rodents are more afraid of a real-life object that they can see rather than the call which is difficult to locate especially at night and difficult to assess the distance between it and the predator. It was suggested that rodents have a hierarchy of responses towards aerial predators such as an owl, freezing when it assessed the predator is quite far away, fleeing when a predator is closer, and fighting back when there is no space or time to run (Eliam et al., 1999). Graded responses to predator cues by Wood mice were also reported by Sanchez-Gonzalez et al. (2018). Indeed, prey may learn the risk level when a more detailed assessment of threats experience (in the form of a visual as opposed to auditory cue) is provided to them (Lima \& Dill, 1990).

Since the 3-D model and owl call had both elicited responses as increased in GUD, it was expected that the response to a combination of both treatments to be additive. However, this is not the case, and the magnitude of response to the combination is in between the owl call and the 3-D model. The likely explanation probably lies in the sequence at which the rats were exposed to predator cue treatment. In the current experiment, all the rats were exposed to predator cues in the following sequence for four days: control, call, 3-D image, and finally the combination of call and 3-D image. It could be that by the time the rats were exposed to the combination treatment, they had become familiar with the environment and predator cues used. A previous study indicated that Norway rats do not show any behavioral signs of stress when exposed to predators' scents in a familiar environment (Stryjek et al., 2018). Simon et al., (2009) stated that rats were able to recognize and respond to changes in predation risk even though the risk was altered. 


\section{CONCLUSION}

In conclusion, the House Rat $R$. tanezumi preferred young coconut flesh over corn, sugar cane, and oil palm fruit, as shown by the significantly $(p<0.05)$ lower GUD for young coconut flesh. All three predator cues (call, 3-D model, and combination of call and 3-D model of Scops Owl) successfully frightened the House Rat leading to significantly higher GUDs of its preferred food. The 3-D owl model elicited the highest fear factor. The finding of this study has potential application in the integrated management plan for the pest in an agricultural and household environment.

\section{ACKNOWLEDGEMENT}

We would like to acknowledge the Faculty of Resource Science and Technology, UNIMAS for use of facilities, and Mr. Trevor Allen Nyaseng and Mr. Isa bin Sait for assistance with experimental set-up. The study was partially funded by a grant from the Malaysian Palm Oil Board to AAT.

\section{REFERENCE}

Abramsky, Z., Strauss, E., Subach, A., Riechman, A., \& Kotler, B.P. 1996. The effect of barn owls (Tyto alba) on the activity and microhabitat selection of Gerbillus allenbyi and $G$. pyramidum. Oecologia, 105(3): 313-319.

Adam, C.L., Williams, P.A., Dalby, M.J., Garden, K., Thomson, L.M., Richardson, A.J. \& Ross, A.W. 2014. Different types of soluble fermentable dietary fibre decrease food intake, body weight gain and adiposity in young adult male rats. Nutrition \& Metabolism, 11(1): 36.

Atta, B., Rizwan, M., Sabir, A.M., Yaqub, M. \& Akhter, M. 2018. Field evaluation of rodenticides treated baits for the effective control of field-rats in rice crop. World Journal of Agricultural Sciences, 14(5): 137-143.

Andru, J., Cosson, J.F., Caliman, J.P. \& Benoit, E. 2013. Coumatetralyl resistance of Rattus tanezumi infesting oil palm plantations in Indonesia. Ecotoxicology, 22(2): 377-386.

Aplin, K.P., Brown, P.R., Jacobs, J., Krebs, C.J., Singleton, G.R. 2003. Field methods for rodent studies in Asia and the Indo-Pacific. Canberra, Australia: Australian Center for International Agricultural Research.

Bessieres, B., Nicole, O. \& Bontempi, B. 2017. Assessing recent and remote associative olfactory memory in rats using the social transmission of food preference paradigm. Nature Protocols, 12: 1415-1436.
Bovet, D. \& Vauclair, J. 2000. Picture recognition in animals and humans. Behavioural Brain Research, 109: 143-165.

Brown, J.S. 1988. Patch use as an indicator of habitat preference, predation risk, and competition. Behavioral Ecology and Sociobiology, 22(1): 37-47.

Brown, J.S. 1999. Vigilance, patch use and habitat selection: Foraging under predation risk. Evolutionary Ecology Research, 1: 49-71.

Burgin, C.J., Colella, J.P., Kahn, P.L. \& Upham, N.S. 2018. How many species of mammals are there? Journal of Mammalogy, 99: 1, 1-14.

Caroline, J., Gross, M.S. \& Spillman, D.M. 2003. Fiber digestion in mammals. Pakistan Journal of Biological Sciences, 6: 1564-1573.

Carlson, K.S., Gadziola, M.A., Dauster, E.S. \& Wesson, D.W. 2018. Selective attention controls olfactory decisions and the neural encoding of odors. Current Biology, 28(14): 2195-2205.

Chalvon- Demersay, Blanchier, F., Tome, D. \& Blais, A. 2017. Animal models for the study of the relationships between diet and obesity: A focus on dietary protein and estrogen deficiency. Frontiers in Nutrition, 4: 1-13.

Duckett, J.E. 1991. Management of the barn owl (Tyto alba javanica) as a predator of rats in oil palm (Elaeis quineensis) plantations in Malaysia. Birds of Prey Bulletin, 4: 11-24.

Eilam, D., Dayan, T., Ben-eliyahu, S., Schulman, I., Shefer, G. \& Hendrie, C.A. 1999. Differential behavioural and hormonal responses of voles and spiny mice to owl calls. Animal Behaviour, 58: 1085-1093.

Hafidzi, M.N. \& Naim, M. 2003. The use of the barn owl, Tylo alba, to suppress rat damage in rice fields in Malaysia. Aciar Monograph Series, 96: 274-276.

Hauze, V., Tran, G., Sauvant, D. \& Bastianelli, D. 2015. Copra meal and coconut by-product. In Feedipedia [WWW Document]. URL https://www.feedipedia.org/node/46 (accessed 03.20.2020)

Hauze, V., Thiollet, H., Tran, G. \& Lebas, F. 2018 a. Sugarcane forage, whole plant. In Feedipedia [WWW Document]. URL https://www.feedi pedia.org/node/14462 (accesssed 05.24.2020)

Hauze, V., Tran, G., Sauvant, D. \& Lebas, F. 2018 b. [WWW Document] Oil palm fronds and oil palm crop residues. URL https://www.feedipedia.org/ node/6916 (accessed 05.24.2020).

Hegab, I.M., Pan, H., Dong, J., Wang, A., Yin, B., Yang, S. \& Wei, W. 2014. Effects of physical attributes and chemical composition of novel foods on food selection by Norway rats (Rattus norvegicus). Journal of Pest Science, 87(1): 99106. 
Hegade, P.B., Desai, V.S., Narangalkar, A.L., Dhekale, J.S. \& Haldankar, P.M. 2017. Influence of weather parameters on incidence of coconut eriophyid mite, Aceria Gueeronis (keifier) (acarina: eriophyidae). International Journal of Agricultural Science and Research (IJASR), 7(6): 355-360.

Hendrie, C.A., Weiss, S.M. \& Eilam, D. 1998. Behavioural response of wild rodents to the calls of an owl: a comparative study. Journal of Zoology, 245: 439-446.

Himsworth, C.G., Parsons, K.L., Jardine, C. \& Patrick, D.M. 2013. Rats, cities, people, and pathogens: a systematic review and narrative synthesis of literature regarding the ecology of rat-associated zoonoses in urban centers. Vector-Borne and Zoonotic Diseases, 13(6), 349-359.

Howald, G.R., Mineau, P., Elliott, J.E. \& Cheng, K.M. 1999. Brodifacoum poisoning of avian scavengers during rat control on a seabird colony. Ecotoxicology, 8(6), 431-447.

Kosoy, M., Khlyap, L., Cosson, J.F. \& Morand, S. 2015. Aboriginal and invasive rats of genus Rattus as hosts of infectious agents. VectorBorne and Zoonotic Diseases, 15(1), 3-12.

Kross, S.M. \& Balwin, R.A. 2016. Gopherbusters? A review of the candidacy of barn owls as the ultimate natural pest control option. In R.M. Timm \& R.A. Balwin (Eds). Proceedings of $27^{\text {th }}$ Vertebrate Pest Conference, pp. 345-352. Davis, United States: University of California.

Kwon, W.B. \& Kim, B.G. 2015. Effects of supplemental beta-mannanase on digestible energy and metabolizable energy contents of copra expellers and palm kernal expellers fed to pigs. Asian Australasian Journal of Animal Sciences, 28(7), 1014-1019.

Lam, Y.M. 1982. Chemical control of rodents. In Rodent Pests of Agricultural Crops in Malaysia (Khoo, KC; Lam, YM; Teoh, CH; Lim, WH and Mohammad, BM eds.). The Malaysian Plant Protection Society, pp. 33-56.

Lima, S.L. \& Dill, L.M. 1990. Behavioral decisions made under risk of predation: a review and prospectus. Canadian Journal of Zoology, 68: 619-640.

Mahlaba, T.A.M., Monadjem, A., Mccleery, R. \& Belmain, R. 2017. Domestic cats and dogs create a landscape of fear for pest rodents around rural homesteads. PLOS ONE, 12(2): 1-9.

Modlinska, K. \& Pisula, W. 2020. The Norway rat, from an obnoxious pest to a laboratory pet. eLife, 9: e50651.
Mohd-Azlan, J., Fang, V.A.M., Kaicheen, S.S., Lok, L. \& Lawes, M.J. 2019. The diversity of understorey birds in forest fragments and oil palm plantation, Sarawak, Borneo. Journal of Oil Palm Research, 31(3): 437-447.

Morris, D.W. \& Davidson, D.L. 2000. Optimally foraging mice match patch use with habitat differences in fitness. Ecology, 81: 2061-2066.

Mui, N.T., Ledin, I. \& Van Binh, D. 2000. Effect of chopping and level of inclusion whole sugarcane in the diet on intake and growth of goats. Livestock Production Science, 66(1): 2534.

Murúa, A.R., Gonzalez, L.A. \& Jofre, C. 1980. Experimental food preferences of two southern chilean rodents. American Society of Mammalogists, 61(1): 138-140.

National Research Council. 1995. Nutrient requirements of laboratory animals: 1995. National Academies Press.

Omar, D., Kasim, A. \& Abidin, C.M.R.Z. 2016. Effects of rodenticide on growth of nestling Barn Owl, Tyto alba javanica in oil palm plantations. Journal of Oil Palm Research, 28(1): 16-25.

Orrock, J.L., Danielson, B.J. \& Brinkerhoff, R.J. 2004. Rodent foraging is affected by indirect, but not by direct, cues of predation risk. Behavioral Ecology, 15(3), 433-437.

Pimsai, U., Pearch, M.J., Satasook, C., Bumrungsri, S. \& Bates, P.J.J. 2014. Murine rodents (rodentia:murinae) of the Myanmar-ThaiMalaysian peninsula and Singapore: taxanomy, distribution, ecology, conservation status, and illustrated identification keys. Boon zoological Bulletin, 63(1): 15-114.

Pongrácz, P. \& Altbäcker, V. 2000. Ontogeny of the responses of European rabbits (Oryctolagus cuniculus) to aerial and ground predators. Canadian Journal of Zoology, 78(4): 655-665.

Puan, C.L., Goldizen, A.W., Zakaria, M., Hafidzi, M.N. \& Baxter, G.S. 2011. Absence of differential predation on rats by Malaysian barn owls in oil palm plantations. Journal of Raptor Research, 45(1): 71-78.

Puan, C.L. 2013. Integrating ecology into rodent pest management in oil palm agroecosystem. Serdang, Selangor: Universiti Putera Malaysia Press.

Puan, C.L., Yong, D.L., Azhar, B., Phua, M.H. \& Lim, K.C. 2015. Ecological correlations of nocturnal bird assemblages in Malaysian Borneo. Forktail, 31: 82-86.

Pulliam, H.R. 1974. On the theory of optimal diets. The American Naturalist, 108(959): 59-74. 
Pyke, G.H. 1984. Optimal foraging theory: a critical review. Annual Review of Ecology and Systematics, 15(1): 523-575.

Quy, R.J., Cowan, D.P., Prescott, C.V., Gill, J.E., Kerins, G.M., Dunsford, G. \& Macnicoll, A.D. 1995. Control of a population of Norway rats resistant to anticoagulant rodenticides. Pesticide Science, 45(3): 247-256.

Rehman, Q.S.U., Ali, K.W., Ali, W.S.M., Waqar, M., Muhammad, N., Abdul, S. \& Ullah, K.A. 2019. Damage impact of vertebrate pests on different crops and stored food items. GSC Biological and Pharmaceutical Sciences, 6(1): 16-20.

Sanchez-Gonzalez, B., Planillo, A., Navarro-Castilla, A. \& Barja, I. 2018. The concentration of fear: mice's behavioural and physiological stress responses to different degrees of predation risk. The Science of Nature, 105(1-2): 16.

Salim, H., Noor, H.M., Hamid, N.H., Omar, D., Kasim, A. \& Abidin, C.M.R.Z. 2014. Secondary poisoning of captive barn owls, Tyto alba javanica, through feeding with rats poisoned with chlorophacinone and bromadiolone. $J$ Oil Palm Res, 26(1): 62-72.

Serieys, L.E., Bishop, J., Okes, N., Broadfield, J., Winterton, D.J., Poppenga, R.H. \& O’Riain, M.J. 2019. Widespread anticoagulant poison exposure in predators in a rapidly growing South African city. Science of the Total Environment, 666: 581-590.

Sih, A. \& Christensen, B. 2001. Optimal diet theory: when does it work, and when and why does it fail? Animal Behaviour, 61(2): 379-390.

Simon, N.W., Gillbert, R.J., Mayse, J.D., Bizon, J.L. \& Setlow, B. 2009. Balancing risk and reward: a rat model of risky decision-making. Neoropsychopharmacology, 34(10): 22082217.

Singleton, G.R. 2003. Impacts of rodents on rice production in Asia. Los Banos, Philippines: IRRI Discussion Paper Series No. 45.

Singleton, G.R., Jacob, J. \& Krebs, C.J. 2005. Integrated management to reduce rodent damage to lowland rice crops in Indonesia. Agriculture, Ecosystems \& Environment, 107(1): 75-82.

Sivy, K.J., Ostoja, S.M., Schupp, E.W. \& Durham, S. 2011. Effects of rodent species, seed species, and predator cues on seed fate. Acta Oecologica, 37(4): 321-328.
Smal, C.M. 1990. Research on the use of barn owl Tyto alba for biological control of rats in oil palm plantaions: 1986-1989. In Jalani, S., Zin, Z.Z., Paranjothy, K., Arrifin, D., Rajanaidu, N., Cheah, S.C., Basri, M.W., Henson, I.E. (Eds), In Proceedings of 1989 International Palm Oil Development Conference - Agriculture. Palm Oil Research Institute of Malaysia, Kuala Lumpur, pp. 342-356.

Stenseth, N.C., Leirs, H., Skonhoft, A., Davis, S.A., Pech, R.P., Andreassen, H.P. \& Zhang, Z. 2003. Mice, rats, and people: the bioeconomics of agricultural rodent pests. Frontiers in Ecology and the Environment, 1(7): 367-375.

Strand, T.M. \& Lundkvist, A. 2019. Rat-borne diseases at the horizon. A systematic review on infectious agents carried by rats in Europe 1995-2016. Infection Ecology \& Epidemiology, 9(1): 1553461.

Stryjek, R., Mioduszewska, B., Spaltabaka-Gedek, E. \& Juszczak, G. 2018. Wild norway rats do not avoid predator scents when collecting food in a familiar habitat: a field study. Scientific Reports, 8: 9475.

Tuen, A.A. \& Brown, J.S. 1996. Evaluating habitat suitability for tree squirrels in a sub-urban environment. Malaysian Applied Biology, 25: 1-8.

Wang, X., Zanette, L. \& Zou, X. 2016. Modelling the fear effect in predator-prey interactions. Journal of mathematical biology, 73(5): 11791204.

Whishaw, I.Q. \& Whishaw, G.E. 1996. Conspecific aggression influences food carrying: studies on a wild population of Rattus norvegicus. Aggressive Behavior: Official Journal of the International Society for Research on Aggression, 22(1): 47-66.

Witmer, G.W. 2004. Rodent ecology and plague in North America, in: Proceedings of the 19th International Congress of Zoology. China Zoological Society, Beijing, pp. 154-156.

Wood, B.J. \& Chung, G.F. 2003. A critical review of the development of rat control in Malaysian agriculture since the 1960s. Crop Protection, 22(3): 445-461.

Wynn, T. 2017. Nutritional studies on mature and immature coconut meat and coconut water. Yadanabon University Research Journal, 8(1). 